\title{
The Study of Cold Stress - Induced Changes in Rat Mesovarium’s Mast Cell Size and Structure in Relation with Estrous Cycle
}

Tumenbayar B ${ }^{1}$, Tsolmon $D^{1}$, Suvdaa $B^{2}$, Enkhzul B ${ }^{2}$, Chimegsaikhan $\mathbf{S}^{2}$, Altangadas $\mathrm{D}^{2}$, Naranbat $\mathrm{B}^{2}$, Munkhzol $\mathbf{M}^{2}$ and Bayarmaa $\mathrm{E}^{2}$

${ }^{1}$ Department of Histology, Mongolian National University of Medical Sciences, Ulaanbaatar, Mongolia

${ }^{2}$ Department of Pathology, Mongolian National University of Medical Sciences, Ulaanbaatar, Mongolia

*Corresponding author: Tumenbayar B, Department of Histology, Mongolian National University of Medical Sciences, Ulaanbaatar, Mongolia, Tel: +976-99192441; Email: tumenbayar@mnums.edu.mn

Received date: January 18, 2019; Accepted date: January 28, 2019; Published date: January 31, 2019

Copyright: (c) 2019 Tumenbayar B, et al. This is an open-access article distributed under the terms of the Creative Commons Attribution License, which permits unrestricted use, distribution, and reproduction in any medium, provided the original author and source are credited.

\begin{abstract}
The climate of Mongolia is dry and extreme, with cold seasons during the 5-7 months of year, which is one of the causes of cold-borne disorders occurring in people. In our country, there are cases of women with inflammatory disease of reproductive organ too. Although the researches on ovarian mast cells have been common so far, the researches on mesovarium mast cells, which have good blood and nerve supply, are pretty uncommon. The researches on cold stress induced changes in mesovarium mast cells' number, size and structure in relation with menstrual cycle hasn't been done yet in our country. In our study, we have chosen 16 rats in control group and 48 rats in cold stress group, a total of 64 rats. The cold stress group was divided again into 3 groups (16:16:16) and underwent daily cold stress (refrigerator- $15^{\circ} \mathrm{C}$ ) from 8:00 am-11:00 am for 7, 14, 21 days in order to generate cold stress model. The number, shape, structural changes, size, perimeter, length and width of the mesovarium mast cell were determined. The determination of estrous cycles was carried out at 8 am on test day by taking a smear from the vagina using Papanicolaou test and the phases of estrous cycle was determined by histological test.
\end{abstract}

Keywords: Mast cell; Estrous cycle; Cold stress

\section{Introduction}

The climate of Mongolia is dry and extreme, with cold seasons during the 5-7 months of year, which is one of the causes of cold-borne disorders occurring in people. In our country, there are cases of women with uterine inflammatory disease-3547, fallopian tube and ovarian inflammation-3953, infertility-263, miscarriage-372, premature birth-5304 a year on average among 865,949 women of reproductive age (15-49) [1]. However, there is no fundamental research on the causes of cold in these disorders. On account of above, it became the reason of conducting this research. Female animals are typically more sensitive to strong physiological stress. During the chronic cold stress, the changes in the females' reproductive system play a key role in their bodies [2]. An effect of cold stress changes female sex hormones and leads to irregulation of estrous cycle [3-5].

In particular, due to the effect of cold stress, the activation of nucleus of Locus coeruleus (LC) in the pons of brainstem consisting of neurons which secrete noradrenalin causes the activation of ovarian sympathetic nerve [6-14]. Additionally, loss of ovarian morphology and regulation of endocrine results in estrous cycle disturbance $[9,15]$. The activation of ovarian mast cell interacts directly with the phases of estrous cycle and sex hormones [4]. The mast cells synthesize receptors of estrogen and progesterone [16].

During the proestrus of estrous cycle, the estrogen and progesterone hormones are increased until highest level. At this time, ovarian mast cell activates, the number of mast cell in a certain area grows and the size and degranulation increase too.

When level of estrogen hormone decreases, number and activation of mast cell decreases [4,17]. Due to the effect of estrogen and progesterone, mast cell degranulates and also migrates to uterus, and may prepare uterus wall for embryo implantation [18]. The histamine and serotonin mediators that secrete from mast cells increase the permeability of vessel, blood flows of ovary, production of steroid hormone and the number of ovulation. During the proestrus cycle, artery of ovary weakens at maximum level because of histamine. As a result, the eosinophil, lymphocyte and monocytes with estrogen receptors migrate to connective tissues, and then secrete inflammatory mediators. Peroxidase enzyme secreted from eosinophil boosts mast cell activation anew. Heparin which secretes from mast cell prevents from blood clot during ovulation [17,19]. For women who have healthy reproductive organs, mast cells are dense, metachromatic and have large numbers of granules; furthermore depending on menstruation cycle mast cells' number and density vary; on the other hand for women with reproductive system loss, the number of mast cell in a certain area is lower, the density is declined, and there is no granule, histamine and anaphylactic granule [20].

Cold is one of the factors that directly stimulate mast cells [21-23]. The chronic cold stress increases the number of mast cell by five times, increases the level of activation to its highest and changes its microstructure $[24,25]$.

It has been observed that, in some mast cells, there are mixed degranulation of two types of hyper-sensitivity, which are immediate (Anaphylactic Reaction) and delayed. The most of activated mast cells occur with delayed hypersensitivity type degranulation [26]. Due to the adverse effects of cold and unfavorable environment, the nerve growth factor (NGF), calcitonin gene-related peptide (CGRP), neurokinin A and substance $\mathrm{P}$ are secreted from the end of sensory neurons. Mast cells have auto-receptors which bind with NGF [27].

NGF activates mast cells directly and plays a huge role in increase of number of mast cells (hyperplasia), degranulation release of histamines 
[21,26,27]. Also mast cells become hyperplastic or increases in number with the effect of NGF, IL-3, IL-4 and Stem cell factor The mechanism of mast cells' size enlargement or hypertrophy is currently unknown [26].

Some researchers have found that mast cells increases in size by 12 to 21 times as a result of stress. Besides, during stress, mast cells migrate largely from the bone marrow to the peripheral organs because of increase in the activation of hypothalamic-pituitary-adrenal axis. This shows that mast cells are the part of the adaptation process during stress [28]. Although the researches on ovarian mast cells have been common so far, the researches on mesovarium mast cells, which have good blood and nerve supply, is pretty uncommon In our country, the comprehensive researches on cold stress induced changes in mesovarium mast cells' number, size and structure in relation with menstrual cycle hasn't been done yet.

\section{Objective}

To investigate the changes in mesovarium mast cells' number (density), size, and structure in relation with estrous cycle of cold stress exposed rats.

\section{Materials and Methods}

\section{The method of creating cold stress}

The strong and constantly chronic cold stress model developed by Russian Federation scientists Avsence AP (1989) and Melovanov AP (1991) was chosen. In our study, a total of 64 Wistar breed rats were divided into 4 groups that are control group-15 rats and cold stress 16:16:16 rats. The cold stress for experimental animals was created for 7, 14 and 21 days every day from 8: 00-11: 00 am through putting them at the $-15^{\circ} \mathrm{C}$ cold refrigeration.

\section{Method of histologic sample preparation}

When ending the 7, 14 and 21 day cold stress experiments, a sample from 16:16:16 rats' mesovarium was taken and prepared block according to the sequence of histologic sample preparation and stained by hematoxyl-eosine. The samples were compared with the control group under microscope.

\section{Taking photos of the microscopic samples}

The AmScope MU 500 microscopic camera was installed on the "Olympus" light microscope, and the sample were enlarged by $4 \times 10$, $10 \times 10$, and $40 \times 10$ and the density, shape and structural changes were evaluated. The micro-image was captured and the cells' area, perimeter, length and width was calculated by the "Discus" software and the research work results were then confirmed.

\section{Analyzation of histologic sample}

- Mesovarium mast cells' density

- Mesovarium mast cells' shape and structure

- Mesovarium mast cells' area, perimeter, length and width

- To determine proestrus, estrus, metestrus, dioestrus phases of estrus cycle by uterus smear analyzation

\section{Identification of phases of estrus cycle}

Samples for the morphological studies were collected every day at 8.00. Vaginal secretions were collected with micropipette containing $200 \mu \mathrm{L}$ of $0.9 \% \mathrm{NaCl}$ by inserting the tip into the vagina. One drop of vaginal fluid was placed onto a clean glass slide and smeared. Unstained smears were observed with a AmScope MU 500 microscope and photomicrographs of the estrous cycle stages. Alternatively, smears were also used Papanicolaou test to enable differentiation of the stages.

- Diestrus: Stringy mucous in which are entangled many leucocytes and a few nucleated epithelial cells

- Proestrus: Largely small, round, nucleated epithelial cells, singly or in sheets. None to few leucoytes.

- Estrus: Contains hundreds of large cornified cells (squames) with degenerate nuclei.

- Metestrus: Many leucocytes and a few cornified cells.

\section{Data collection methods}

\section{Selection}

- The rats and rat number in the experimental study were selected according to the animal selection standard for the study

- Each quantitative data is selected

\section{Statistical analysis of results}

The result of our research is based on the basic method of biostatistics (N. Pohoninsky, Yu U. Urbakh, G. Lactin, TJ Norman, and Balley) and mean value, standard deviation, average error, upper and lower variance and correlation coefficients were determined by the commonly-known method.

The mathematical functions for statistical process were perfomed by ${ }^{*}$ SPSS-21.0 for Windows statistical program and Microsoft Office Excel Program, and the programmed graphs, drawings and spreadsheets were done by Microsoft Office 2007.

Student value ( $\mathrm{t}$ ) was determined when comparing mean indications. $\mathrm{P}$ value in accordance with Student $\mathrm{t}$ value is determined. The probability threshold is assumed to have a statistically significant difference between the two parameters when the $\mathrm{p}$ value is less than $\mathrm{p}<0.05$.

\section{Results}

The vaginal smear from female rats that went through 7 (group I), 14 (group II), 21 days (group III) of cold stress showed the structures which are seen in every estrous cycle phase were observed.

Comparing the experimental group's estrous cycle phase duration with the control group', the duration of diestrus phase was extended by following days: 7 days: 2.7 ( $\mathrm{p}=0.0001), 14$ days: 3.1 ( $\mathrm{p}=0.0001$ ), 21 days: $3.4(\mathrm{p}=0.0001)$. The duration of total cycle was lengthened by following days too: Group I: 2.8 ( $\mathrm{p}=0.0001)$, Group II: 3.2 ( $\mathrm{p}=0.0001)$, Group III: $3.7(\mathrm{p}=0.0001)$ (Tables 1-3) and (Figures 1-11). 
Citation: Tumenbayar B, Tsolmon D, Suvdaa B, Enkhzul B, Chimegsaikhan S, et al. (2019) The Study of Cold Stress - Induced Changes in Rat Mesovarium's Mast Cell Size and Structure in Relation with Estrous Cycle. J Cytol Histol 10: 529.

Page 3 of 7

\begin{tabular}{|l|l|l|l|}
\hline & Group I & Group II & Group III \\
\hline Diestrus (days) & $2.7(p=0.0001)$ & $3.1(p=0.0001)$ & $3.4(p=0.0001)$ \\
\hline Total cycle (days) & $2.8(p=0.0001)$ & $3.2(p=0.0001)$ & $3.7(p=0.0001)$ \\
\hline As a control group compare per cold stressed groups; $p$ value is highly significant at the $p \leq 0.0001$ & \\
\hline
\end{tabular}

Table 1: Lengthen of duration of diestrus phase and total cycle.

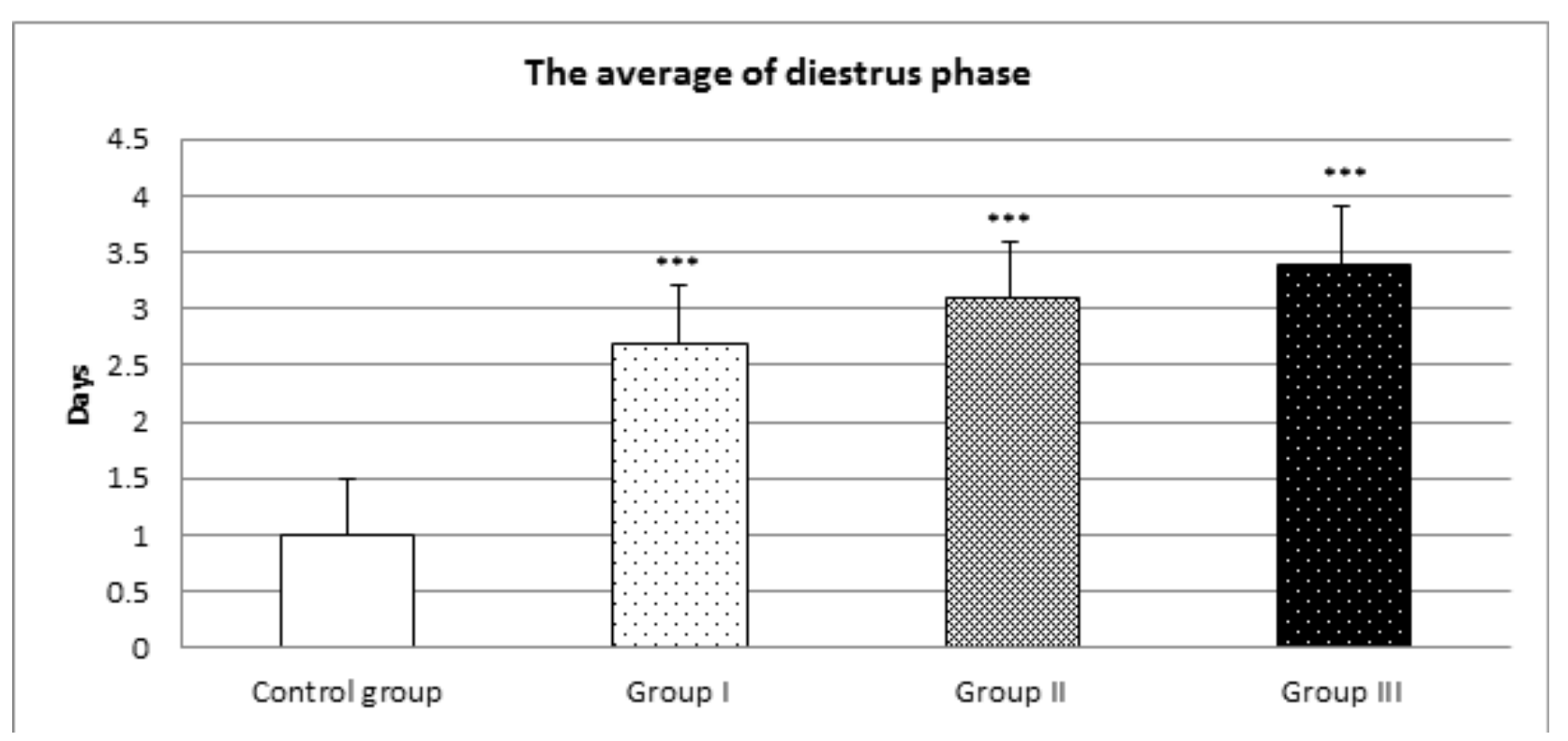

Figure 1: Comparing the average duration of estrous cycle's diestrus phase. ${ }^{\star *}$ As a control group compare per cold stressed groups; $\mathrm{p}$ value is highly significant at the $\mathrm{p} \leq 0.0001$.

\begin{tabular}{|l|l|l|l|l|l|l|}
\hline & $\begin{array}{l}\text { Number (in certain } \\
\text { area) }\end{array}$ & Length $(\boldsymbol{\mu m})$ & Width $(\boldsymbol{\mu m})$ & Square $(\boldsymbol{\mu m} 2)$ & Perimeter $(\boldsymbol{\mu m})$ & $\begin{array}{l}\text { Degranulation } \\
(\boldsymbol{p} \text { oint) }\end{array}$ \\
\hline Proestrus & 2 & $16.15 \pm 2.19$ & $9.77 \pm 1.73$ & $122.5 \pm 26.87$ & $45.33 \pm 7.5$ & 3 \\
\hline Estrus & 2 & 12 & 7.84 & 67.53 & 33.39 & 2 \\
\hline Metestrus & 1 & $10.03 \pm 0,5$ & 4.68 & 37 & 26.8 & 1 \\
\hline Diestrus & 1 & $10.03 \pm 0.57$ & $6.14 \pm 0.91$ & $51.13 \pm 10.22$ & $30.12 \pm 1.66$ & 1.5 \\
\hline P value & $\mathrm{p}=0.006$ & $\mathrm{p}=0.001$ & $\mathrm{p}=0.002$ & $\mathrm{p}=0.004$ & $\mathrm{p}=0.004$ & $\mathrm{p}=0.002$ \\
\hline A & & & & & \\
\hline
\end{tabular}

As a control group compare per cold stressed groups; $p$ value are high significant at the $p \leq 0.001$, significant at the $p \leq 0.05$. $P$ value $(P+E)$ and $(M+D)$ is difference between proestrus phase (proestrus+estrus) and diestrus phase (metestrus+diestrus)

Table 2: Changes in the characteristics of mesovarium mast cells of control group rats.

\begin{tabular}{|c|c|c|c|c|c|c|}
\hline & $\begin{array}{l}\text { Number (in certain } \\
\text { area) }\end{array}$ & $\begin{array}{l}\text { Length } \\
(\mu \mathrm{m})\end{array}$ & Width $(\mu \mathrm{m})$ & Square $(\mu \mathrm{m} 2)$ & Perimeter $(\mu \mathrm{m})$ & $\begin{array}{l}\text { Degranulation } \\
\text { (point) }\end{array}$ \\
\hline Control group & $1.3 \pm 0.52$ & $11.48 \pm 2.89$ & $6,97 \pm 1,98$ & $67.24 \pm 34.38$ & $33.49 \pm 7.5$ & 0.78 \\
\hline Group I & $5 \pm 3.68(p=0.0001)$ & $\begin{array}{l}15.35 \\
(p=0.005)\end{array} \pm 2.34$ & $8.37 \pm 2.5(p=0.005)$ & $120.96 \pm 41.91(p=0.008)$ & $45.83 \pm 8.7(p=0.004)$ & $3(p=0.0001)$ \\
\hline
\end{tabular}


Citation: Tumenbayar B, Tsolmon D, Suvdaa B, Enkhzul B, Chimegsaikhan S, et al. (2019) The Study of Cold Stress - Induced Changes in Rat Mesovarium's Mast Cell Size and Structure in Relation with Estrous Cycle. J Cytol Histol 10: 529.

Page 4 of 7

\begin{tabular}{|l|lr|lr|lr|l|l|l|l|l|}
\hline Group II & $\begin{array}{l}4.4 \pm \\
(p=0.0001)\end{array}$ & 2.06 & $\begin{array}{l}15.86 \pm \\
(p=0.001)\end{array}$ & 2.27 & $\begin{array}{l}10.34 \pm \\
(p=0.003)\end{array}$ & 2.39 & $125.93 \pm 44.9(p=0.004)$ & $43.99 \pm 11.1(p=0.02)$ & $2.2 \pm 05(p=0.0001)$ \\
\hline Group III & $\begin{array}{l}4.7 \pm \pm \\
(p=0.0001)\end{array}$ & 1.83 & $\begin{array}{l}22.24 \pm \\
(p=0.0001)\end{array}$ & 3.82 & $\begin{array}{l}12.5 \pm \\
(p=0.001)\end{array}$ & 3.56 & $203.81 \pm 52.11(p=0.0001)$ & $\begin{array}{l}60.28 \\
(p=0.0001)\end{array}$ & 15.72 & $0.31 \pm 0,49(p=0.0001)$ \\
\hline
\end{tabular}

As a control group compare per cold stressed groups; $p$ value are highly significant at the $p \leq 0.0001$ and high significant at the $p \leq 0.001$, significant at the $p \leq 0.05$.

Table 3: Changes in the characteristics of mesovarium mast cells of experimental groups.

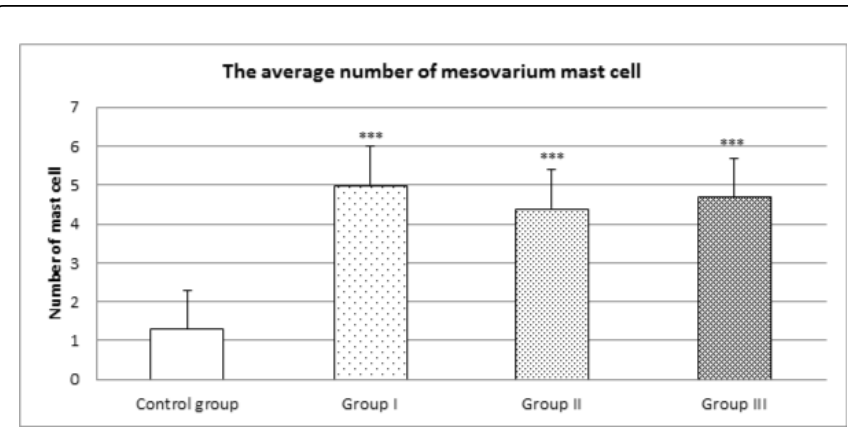

Figure 2: Comparison of the average number of mesovarium mast cells. ${ }^{* * *}$ As a control group compare per cold stressed groups; $\mathrm{p}$ value is highly significant at the $\mathrm{p} \leq 0.0001$.

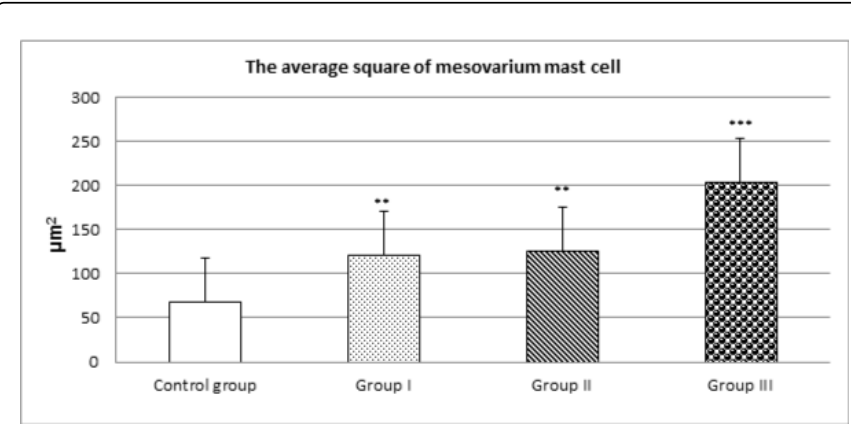

Figure 3: Comparing the average square of mesovarium mast cells As a control group compare per cold stressed groups; $p$ value is ${ }^{\star *}$ high $\mathrm{p} \leq 0.008$ and ${ }^{\star *}$ highly significant at the $\mathrm{p} \leq 0.0001$.

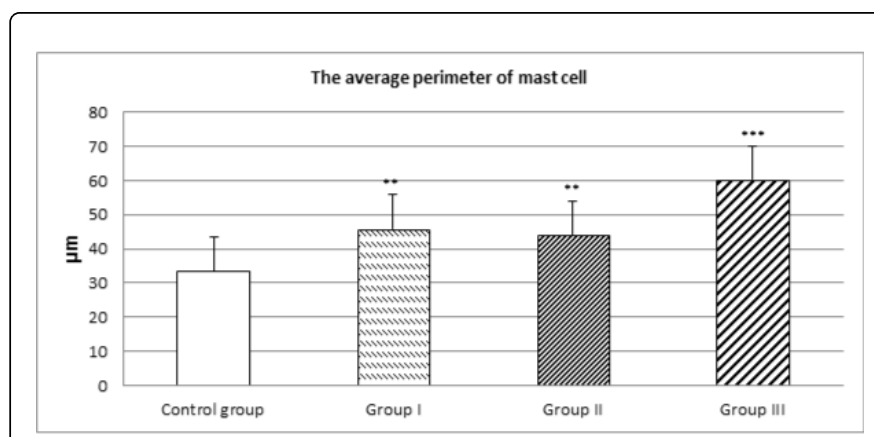

Figure 4: Comparing the average perimeter of control group's mesovarium mast cells. As a control group compare per cold stressed groups; $\mathrm{p}$ value is ${ }^{* *}$ highly $\mathrm{p} \leq 0.0001,{ }^{* *}$ high significant at the $\mathrm{p} \leq 0.02$.

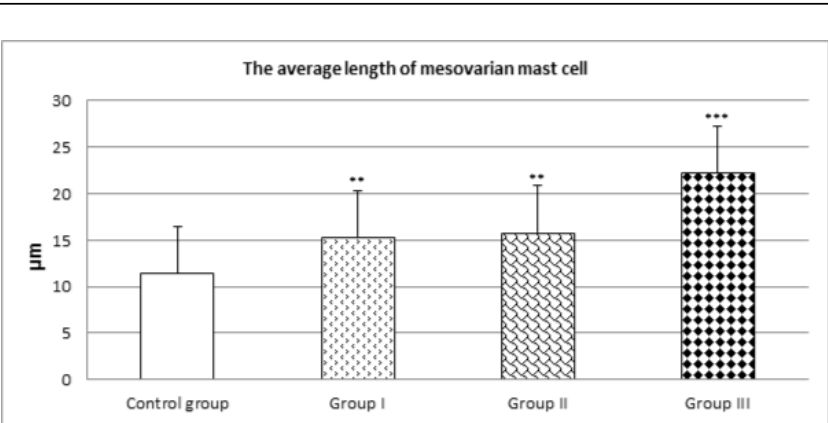

Figure 5: Comparing the average length of mesovarium mast cells. As a control group compare per cold stressed groups; $p$ value is ${ }^{\star *}$ high $\mathrm{p} \leq 0.005$ and ${ }^{\star * *}$ highly significant at the $\mathrm{p} \leq 0.0001$. 
Citation: Tumenbayar B, Tsolmon D, Suvdaa B, Enkhzul B, Chimegsaikhan S, et al. (2019) The Study of Cold Stress - Induced Changes in Rat Mesovarium's Mast Cell Size and Structure in Relation with Estrous Cycle. J Cytol Histol 10: 529.

Page 5 of 7

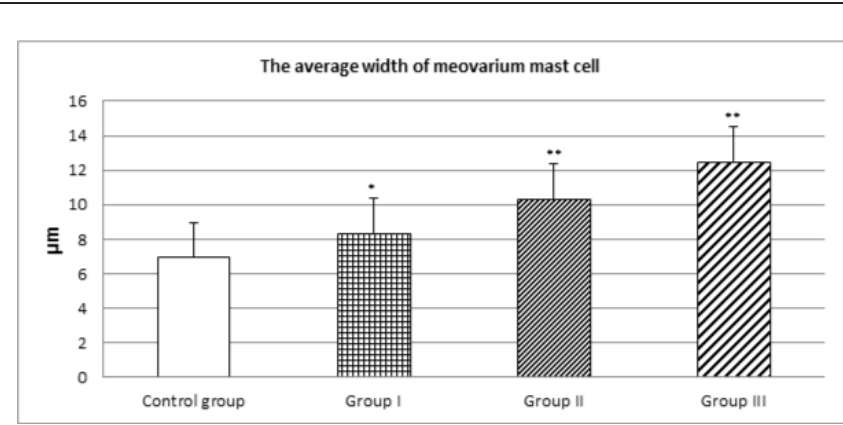

Figure 6: Comparing the average width of the mesovarium mast cells. As a control group compare per cold stressed groups; $p$ value is **high $\mathrm{p} \leq 0.005$ and ${ }^{*}$ significant at the $\mathrm{p} \leq 0.2$.

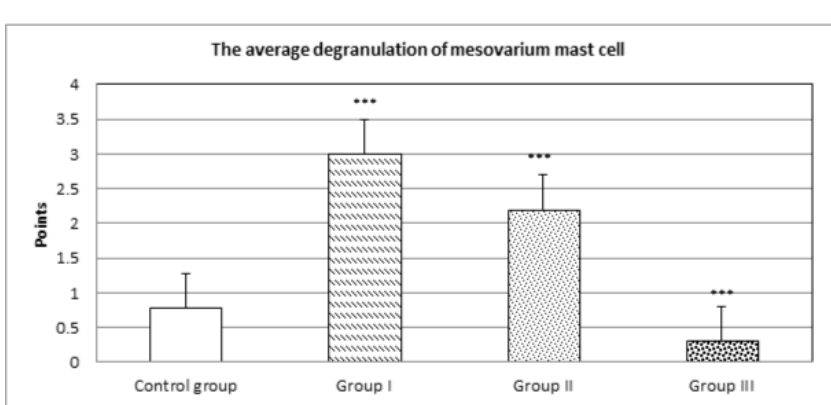

Figure 7: Comparing the average granule density of mesovarium mast cells. ${ }^{* *}$ As a control group compare per cold stressed groups; $\mathrm{p}$ value is highly significant at the $\mathrm{p} \leq 0.0001$.

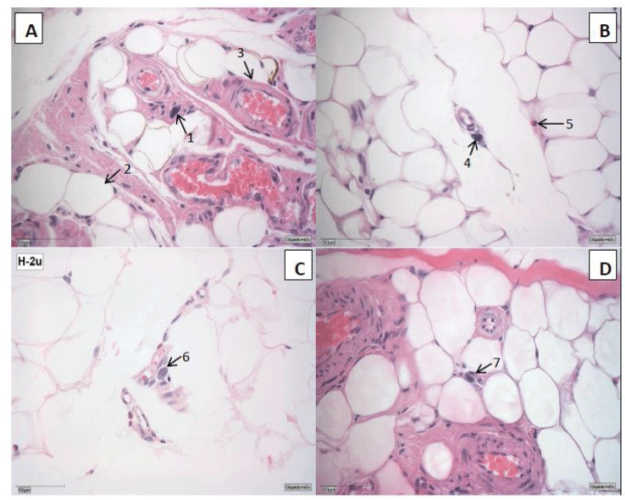

Figure 8: Mesovarium tissue sample of control group rat. (H\&E stain; 40x) A. Mesovarium tissue sample of proestrus phase: Mast cell is oval shaped that contains many granules. 1. Mast cell 2. White adipocyte 3. Blood vessel. B. Mesovarium tissue sample of estrus phase: Mast cell is irregular round shaped and degranulated 4. Mast cell 5. Eosinophil C. Mesovarium tissue sample of metestrus phase: Mast cell is round that contains no granules 6. Mast cell. D. Mesovarium tissue sample of diestrus phase: Mast cell is small and round shaped that contains no granules 7. Mast cell.

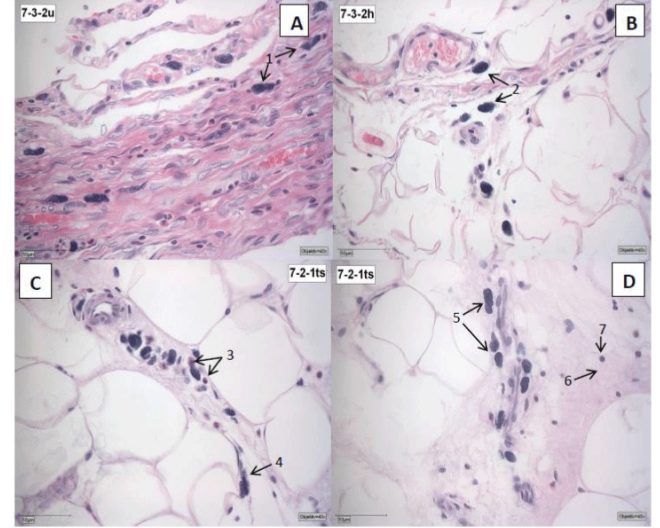

Figure 9: Mesovarium tissue sample of experimental group I (H\&E stain; 40x). The number of mast cell per unit is increased, the mast cells are activated, the density of granules is increased and the mast cells are increased in their size. A. Mesovarium tissue sample of proestrus phase: Mast cells are elongated and degranulated. 1. Mast cell. B. Mesovarium tissue sample of estrus phase: Mast cells are irregular round shaped and degranulated. 2. Mast cell. C. Mesovarium tissue sample of metestrus phase: Mast cells are round or elongated and degranulated 3. Eosinophil 4. Mast cell. D. Mesovarium tissue sample of diestrus phase: Mast cells are elongated and degranulated. 5. Mast cell. 6. New brown adipocyte 7. Nucleus of brown adipocyte.

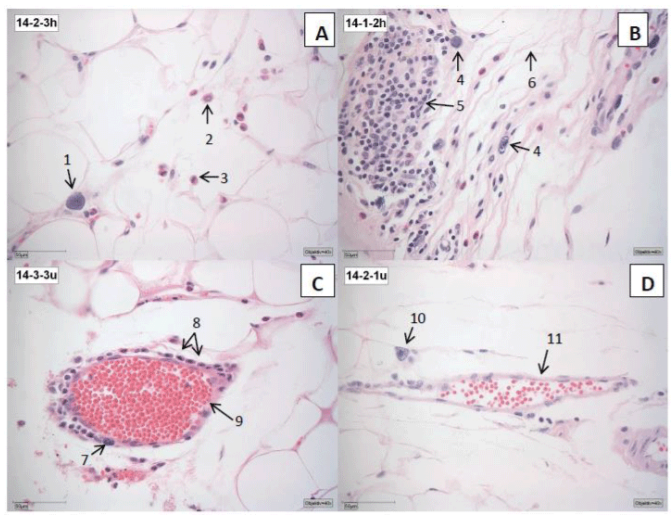

Figure 10: Mesovarium tissue sample of experimental group II (H\&E stain; 40x). Density of granules is decreased in mast cells. A number of eosinophil and leukocytes are increased. Blood vessels are dilated. A. Mesovarium tissue sample of proestrus phase: Mast cells are round shaped and degranulated. 1. Mast cell. 2. Immature eosinophil 3. Eosinophil. B. Mesovarium tissue sample of estrus phase: Mast cells are round and oval shaped and degranulated. 4. Mast cell 5. Leukocytes 6. Collagen fiber. C. Mesovarium tissue sample of metestrus phase: Mast cells are round and degranulated. 7. Mast cell 8. Immature mast cells 9. Blood vessel. D. Mesovarium tissue sample of diestrus phase: Mast cell irregular round and degranulated. 10. Mast cell. 11. Blood vessel. 


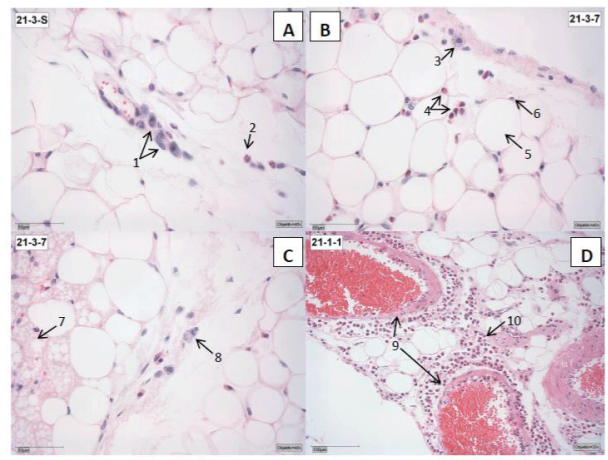

Figure 11: Mesovarium tissue sample of experimental group III (H\&E stain; 40x). The density of granules in cytoplasm of the mast cells is decreased because of degranulation. So they are stained hypochromic. As comparing with the previous groups, large number of eosinophils has immigrated, created infiltration and dilated blood vessels. Brown adipocytes increased in mesovarium tissue. A. Mesovarium tissue sample of proestrus phase: Mast cells are irregular elongeted shaped and degranulated. 1. Mast cell. 2. Eosinophil. B. Mesovarium tissue sample of estrus phase: Mast cell is round. There are few granuls in cytoplasm of the mast cell. 3. Mast cell 4. Eosinophils 5. Adipocyte 6. Nucleus of adipocyte. C. Mesovarium tissue sample of metestrus phase: Mast cells are irregular elongeted and no granulated. 7. Brown adipocyte 8. Mast cell. D. Mesovarium tissue sample of diestrus phase: 9. Blood vessels 10. Eosinipils.

\section{Discussion}

In Gordyenko's research named "Changes of reproductive system's structure and function during cold stress" in 1998, they created cold stress to the rat at $-15 \mathrm{C}$ for 10:15:30 days, and then investigated the rat's mesovarium mast cells, estrus cycle change, and their correlation. As a result of this research, the rat's estrus cycle period was lost due to cold stress, and the mast cell's number, size, density of granules increased irrelavently with estrus cycle. The Deepthi D'Souza, Monika Sadananda's "Estrus Cycle Phase-Dependent Changes in Anxiety and Depression Like Profiles in the Late Adolescent Wistar Kyoto Rat" 2017 research result shows that due to uncomfortable condition proestrus phase, (estrus+proestrus) was shortened $(\mathrm{p}=001)$, diestrus phase (metestrus+diestrus) was lengthened $(\mathrm{P}=0.0179)$.

In the research of Boes Tanner, Levy Dan " Influence of sex, estrus cycle and estrogen on intracranial dural mast cells" 2012, mast cell 's density was increased during proestrus $(\mathrm{p}<0.01)$. The Gaytan F, Aceitero J, Bellido C, Sanchez-Criado JE, Aguilar E's "Estrous cycle related changes in mast cell numbers in several ovarian compartments in the rat" 1991 experiment result shows that mast cell number of ovary was increased $(\mathrm{p} \leq 0.01)$ during stress.

The research of Santos J, Yang PC, Söderholm JD, Perdue MH "Role of mast cells in chronic stress induced colonic epithelial barrier dysfunction in the rat" 2001 concluded that mast cell's number and activity was changes $(\mathrm{p}<0.05)$ due to chronic stress. In our study it is directly related to the estrus cycle of control group rat, differences of average characteristics of mesovarium mast cells in proestrus phase (estrus+proestrus) and diestrus phase (metaestrus+diestrus) was:
Number of cell $(\mathrm{P}=0.006)$, cell density $(\mathrm{P}=0.002)$, cell length $(\mathrm{P}=0.001)$, cell width $(\mathrm{P}=0.012)$, cell square $(\mathrm{P}=0.002)$, cell perimeter $(\mathrm{P}=0.004)$. In proestrus phase the mast cells were increased in their size, number and density. Average characteristics of mesovarium mast cells of rat that experienced cold stress were changed irrelevant to estrus cycle.

When comparing the characteristics of mesovarium mast cells of control group rats to the experiment group rats that went through 7:14:21 day cold stress, the diestrus phase change was $(\mathrm{P}=0.0001)$ : $(\mathrm{P}=0.0001):(\mathrm{P}=0.0001)$, the number change was $(\mathrm{P}=0.0001)$ : $(\mathrm{P}=0.0001):(\mathrm{P}=0.0001)$, the mast cell density change was $(\mathrm{P}=0.0001)$ : $(\mathrm{P}=0.0001):(\mathrm{P}=0.0001)$, the square change was $(\mathrm{P}=0.008):(\mathrm{P}=0.004)$ : $(\mathrm{P}=0.0001)$, the perimeter change was: $(\mathrm{P}=0.004):(\mathrm{P}=0.02):(\mathrm{P}=0.0001)$, the length change was: $(\mathrm{P}=0.005):(\mathrm{P}=0.001):(\mathrm{P}=0.0001)$, the width change was: $(\mathrm{P}=0.005):(\mathrm{P}=0.003):(\mathrm{P}=0.001)$. The Changes in number, density, square, perimeter, length and width of mast cells of experimental group was directly related to the duration of cold stress.

\section{Conclusion}

The shape of mesovarium mast cells is changed, the mast cells are increased in their number and size as well as the density of mesovarium mast cells is changed due to the cold stress. When extending the cold stress duration, there was a directly-related increase in the size and number of mast cell. On the other hand, when there was an increase in the granules' density of mast cells of rats that had been exposed to the cold stress for a short time, as duration increases, the density of mast cell was decreasing due to degranulation. The cold stress disturbed estrus cycle of rats, and the phase of diestrus was prolonged depending directly on the cold stress duration. When the activation of mast is directly related to the estrus cycle in control group, there is no relationship between changes of mesovarium mast cell and estrus cycle in cold stress exposed rats.

\section{References}

1. The Ministry of Health (2018) General database of statitical information.

2. Gordienko NE (1998) The changes in structure and activity of reproductive system during cold affection.

3. Deepthi D'Souza MS (2017) Estrous cycle phase-dependent changes in anxiety- and depression-like profiles in the late adolescent Wistar-Kyoto Rat. Ann Neurosci 24: 136-145.

4. Boes T, Levy D (2012) Influence of sex, estrous cycle and estrogen on intracranial dural mast cells. Cephalalgia: An international journal of headache 32: 924-931.

5. Bozzo AA, Sonez CA, Monedero Cobeta I (2014) Chronic stress and its effects on adrenal cortex apoptosis in pregnant rats. Biotechnic and histochemistry: Official publication of the Biological Stain Commission 89: 296-303.

6. Pardon MC, Morilak DA (2003) Chronic cold stress sensitizes brain noradrenergic reactivity and noradrenergic facilitation of the HPA stress response in Wistar Kyoto rats. Brain Res 971: 55-65.

7. Park E, Choi CW, Kim SJ (2017) Hochu-ekki-to Treatment Improves Reproductive and Immune Modulation in the Stress-Induced Rat Model of Polycystic Ovarian Syndrome. Molecules 22: 978.

8. Bernuci MP, Leite CM, Barros P, Kalil B, Leoni GB, et al. (2013) Transitory activation of the central and ovarian norepinephrine systems during cold stress-induced polycystic ovary in rats. Journal of neuroendocrinology 25: 23-33.

9. Bernuci MP, Szawka RE, Helena CV, Leite CM, Lara HE, et al. (2008) Locus coeruleus mediates cold stress-induced polycystic ovary in rats. Endocrinology 149: 2907-2916. 
Citation: Tumenbayar B, Tsolmon D, Suvdaa B, Enkhzul B, Chimegsaikhan S, et al. (2019) The Study of Cold Stress - Induced Changes in Rat Mesovarium's Mast Cell Size and Structure in Relation with Estrous Cycle. J Cytol Histol 10: 529.

Page 7 of 7

10. Berridge CW, Waterhouse BD (2003) The locus coeruleus-noradrenergic system: modulation of behavioral state and state-dependent cognitive processes. Brain research Brain research reviews 42: 33-84.

11. Campos AC, Aguiar DC, Guimaraes FS (2013) Animal models of anxiety disorders and stress. Braz J Psychiatry 2: S101-S111.

12. Cerri M, Mastrotto M, Tupone D (2013) The inhibition of neurons in the central nervous pathways for thermoregulatory cold defense induces a suspended animation state in the rat. The Journal of neuroscience 33: 2984-2993.

13. Dorfman M, Arancibia S, Fiedler JL, Lara HE (2003) Chronic intermittent cold stress activates ovarian sympathetic nerves and modifies ovarian follicular development in the rat. Biol Reprod 68: 2038-2043.

14. Dorfman M, Ramirez VD, Stener-Victorin E, Lara HE (2009) Chronicintermittent cold stress in rats induces selective ovarian insulin resistance. Biol Reprod 80: 264-271.

15. Lara HE, Dorfman M, Venegas M, Luza SM, Luna SL, Mayerhofer A, et al. (2002) Changes in sympathetic nerve activity of the mammalian ovary during a normal estrous cycle and in polycystic ovary syndrome: Studies on norepinephrine release. Microsc Res Tech 59: 495-502.

16. Zierau O, Zenclussen AC, Jensen F (2012) Role of female sex hormones, estradiol and progesterone, in mast cell behavior. Frontiers in Immunology 3: 169.

17. Gaytan F, Aceitero J, Bellido C, Sanchez-Criado JE, Aguilar E (1991) Estrous cycle-related changes in mast cell numbers in several ovarian compartments in the rat. Biol Reprod 45: 27-33.

18. Jensen F, Woudwyk M, Teles A, Woidacki K, Taran F, et al. (2010) Estradiol and progesterone regulate the migration of mast cells from the periphery to the uterus and induce their maturation and degranulation. Plos one 5: e14409.
19. Krishna A, Beesley K, Terranova PF (1989) Histamine, mast cells and ovarian function. J Endocrinol 120: 363-371.

20. Bonnar LDBLSJ (1991) The mast cell and histamine concentration of the human post-menopausal uterus. European Journal of Obstetrics \& Gynecology and Reproductive Biology 42: 39-42.

21. Wang R, Yin X, Zhang H, Wang J, Chen L, et al. (2016) Effects of a Moderately Lower Temperature on the Proliferation and Degranulation of Rat Mast Cells. Journal of Immunology Research 2016: 8439594.

22. Graevskaya EE, Akhalaya MY, Goncharenko EN (2001) Effects of cold stress and epinephrine on degranulation of peritoneal mast cells in rats. Bull Exp Biol Med 131: 333-335.

23. Theoharides TC, Alysandratos K-D, Angelidou A (2012) Mast cells and inflammation. Biochim Biophys Acta 1822: 21-33.

24. Kaushik S, Sanchez-Criado JE (2009) Effect of chronic cold stress on intestinal epithelial cell proliferation and inflammation in rats.

25. Santos J, Saperas E, Nogueiras C (1998) Release of mast cell mediators into the jejunum by cold pain stress in humans. Gastroenterology 114: 640-648.

26. Santos J, Yang P, Soderholm J, Benjamin M, Perdue M (2001) Role of mast cells in chronic stress induced colonic epithelial barrier dysfunction in the rat. Gut 48: 630-636.

27. Kleij HP, Bienenstock J (2005) Significance of Conversation between Mast Cells and Nerves. Allergy, Asthma, and Clinical Immunology 1: 65-80.

28. OCA (2011) On the issue of the participation of the mast cell in the development of stress-reaction. 